\title{
Reducing Carbon Emissions in Portugal: The Relative Roles of Fossil-Fuel Prices, Energy Efficiency, and Carbon Taxation $(*)$
}

\author{
Alfredo Marvão Pereira** \\ The College of William and Mary \\ Rui M. Pereira \\ The College of William and Mary
}

College of William and Mary

Department of Economics

Working Paper Number 154

First Version: December 2014

This Version: May 2015

(*) [EDITED] This work was developed in coordination with the Commission for Environmental Tax Reform (Comissão para a Reforma da Fiscalidade Verde) apointed by the Portuguese Government. This paper, as well as all of the documentation produced by the Commission and the evaluation teams, is hosted online at the Portuguese Ministry for the Environment (Ministério do Ambiente, Ordenamento do Território e Energia). 


\author{
COLLEGE OF WILLIAM AND MARY \\ DEPARTMENT OF ECONOMICS \\ WORKING PAPER \# 154 \\ May 2015
}

\title{
Reducing Carbon Emissions in Portugal: The Relative Roles of Fossil-Fuel Prices, Energy Efficiency, and Carbon Taxation $(*)$
}

\begin{abstract}
We assess the relative role of fossil-fuel prices, energy efficiency and carbon taxation in achieving climate policy goals using a dynamic general-equilibrium model of the Portuguese economy featuring endogenous growth and a detailed modeling of public-sector activities. Given the expected evolution of international fossil fuel prices, we show that to reach ambitious domestic reductions in emissions, it is fundamental to promote energy efficiency and to levy a significant carbon tax. Improving energy efficiency and implementing a new carbon tax have significantly different economic and budgetary effects. More energy efficiency reduces emissions and boosts economic performance, but increases public and foreign debt. In turn, the new carbon tax reduces emissions at the risk of jeopardizing economic performance, while the effects on public and foreign debt are more favorable. Thus, the relevance of pursuing both strategies in tandem is clear. We estimate that under the reference-price scenario, a steady energy efficiency gain of 2-2.5\% and a carbon tax of at least $35 €$ per $\mathrm{tCO}_{2}$ are required to achieve the stated goal of reducing carbon dioxide emission by 2030 by an amount equivalent to $40 \%$ of the emissions in 1990. These views were fully integrated in a proposal presented by the Commission for Environmental Tax Reform [CRFV (2014)] to the Portuguese Government in September 2014 and then discussed in Parliament in November 2014, before enacting a new carbon tax on January $1^{\text {st }}, 2015$.
\end{abstract}

Keywords: Fossil-Fuel Prices, Energy Efficiency, Rebound Effects, Carbon Taxation, Economic Effects, Budgetary Effects, Dynamic General-Equilibrium, Endogenous Growth, Portugal.

JEL Classification: D58, H63, O44.

Alfredo Marvão Pereira

Department of Economics, The College of William and Mary, Williamsburg, USA

PO Box 8795, Williamsburg, VA 23187

ampere@,wm.edu

Rui M. Pereira

Department of Economics, The College of William and Mary, Williamsburg, USA

PO Box 8795, Williamsburg, VA 23187

rmpereira@wm.edu 


\section{Introduction}

In Portugal, the last twenty years have witnessed substantial changes in the energy sector and in carbon dioxide emissions from fossil-fuel combustion activities. These constitute the bulk of greenhouse gas (GHG) emissions from energy activities, and about 70\% of GHG emissions in the country. In 1990 - a benchmark year for emissions data defined in the context of the United Nations Framework Convention on Climate Change and the Kyoto Protocol [see, for example Haita (2012) and European Commission (2014a)] - carbon dioxide emissions from fossil-fuel combustion activities amounted to $40.9 \mathrm{Mt} \mathrm{CO}_{2}$. Emissions grew 57\% between 1990 and 2005, the year they reached 64.1 $\mathrm{Mt} \mathrm{CO}_{2}$, the highest level in two decades.. Together, the introduction of natural gas in the late 1990s, the effective promotion of renewable energies, and the European Union Emissions Trading System (ETS) have allowed emissions to drop to 45.3 Mt $\mathrm{CO}_{2}$, a 25\% reduction between 2005 and 2012, a result driven, in part, by weak economic conditions and the recent global financial crisis.

Following these positive outcomes - both in terms of the increased reliance on domestic renewable energies and reductions in GHG emissions - Portugal, together with other European Union Member States, has set forth an ambitious program for 2030 to reduce emissions by 40\%, relative to 1990 levels [see, for example, the national roadmap to low carbon in 2050 from Agência Portuguesa do Ambiente (2012), or the policy framework for climate and energy from 2020 to 2030 from the European Commission (2014b, 2014c)]. Achieving these goals will require a comprehensive package of policy instruments which will demand a multi-pronged approach First, given that Portugal depends on imported fossil fuels to satisfy the bulk of its energy needs, how international prices for the different fuels - oil, natural gas, and coal - will fare in the future will have a direct impact on demand, and thereby also on GHG emissions. Second, there is plenty of evidence that there is substantial potential for adopting cost-effective ways to improve energy efficiency. Finally, there is an ongoing debate on the necessity and the impact of introducing a tax on carbon dioxide emissions. 
The purpose of this paper is to identify the relative role of these three drivers of carbon dioxide emissions in achieving environmental goals in Portugal. Naturally, our main concern is about their effectiveness in reducing emissions. At the same time, we recognize that these three different drivers have very different economic and budgetary repercussions. While increases in fossil-fuel prices result in a net loss of resources for the domestic economy, a carbon tax generates revenues. Finally, more energy efficiency provides the potential for a win-win outcome in terms of environmental as well as economic performance.

We assess the relative role of fossil-fuel prices, energy efficiency and carbon taxation in achieving environmental targets using a dynamic general-equilibrium model of the Portuguese economy that features endogenous growth and a detailed modeling of public-sector activities, both in terms of the different tax revenues and in terms of social-welfare-maximizing public consumption and capital spending. The model further captures the small, open, energyimporting, nature of the Portuguese economy, and is calibrated to replicate its stylized facts over the last two decades. Previous versions of this model were used to evaluate the impact of tax policy [see Pereira and Rodrigues (2002, 2004)], public pension reform [see Pereira and Rodrigues (2007)], and, more recently, other energy and climate policies [see Pereira and Pereira (2013, 2014a, 2014b, 2014c)].

Naturally, the impact of climate policy on economic performance has been a central part of the policy debate [see, for instance, Nordhaus (1993a, 1993b), Babiker et al. (2003), Dissou (2005), Stern (2007), Rivers, (2010), and Morris et al. (2012)]. These impacts have been explored in a general-equilibrium framework [see, for example, Barker et al. (1993), Koeppl et al. (1996), Farmer and Steininger (1999), Heijdra et al. (2006) and Conefrey et al. (2013)]. The key distinguishing feature of our methodological approach is a focus on endogenous growth and the associated treatment of public sector behavior [see Conrad (1999) and Bergman (2005) for literature surveys]. Productivity-enhancing investments in public and human capital, which have been largely overlooked in applied climate policy [van Zon and Yetkiner (2003) and Carraro et al. 
(2012)], are, in addition to private investment, the drivers of endogenous growth. Furthermore, the analysis of the interaction between fiscal policies, public capital, economic growth, and environmental performance has garnished little attention, and then only in a theoretical framework [Bovenberg and de Mooij (1997), Greiner (2005), Fullerton and Kim (2008), Glomm et al. (2008) and Gupta and Barman (2009)].

The remainder of this article is organized as follows. Section 2 presents the dynamic general-equilibrium model and its implementation for the Portuguese case. The next three sections are the core of the paper, and consider in succession the three different drivers of lower emissions. Section 3 focuses on different fossil-fuel price scenarios and their impact. This is the most basic exogenous driver of emissions and economic growth that lies beyond the reach of domestic policy makers. Section 4 addresses the incremental effects of energy efficiency gains when considered in addition to the reference fuel-price scenario. This recognizes that, given the expected evolution of international fossil-fuel prices, promoting energy efficiency is the most basic tool at the disposal of domestic authorities Section 5 , in turn, focuses on the effects of a carbon tax in an environment subject to the reference international fuel-price scenario and energy efficiency gains. Section 6, presents and discusses the relative roles of the three mechanisms under consideration. Finally, Section 7 wraps up and discusses a few policy implications.

\section{The Dynamic General-Equilibrium Model of the Portuguese Economy}

In this section we present the dynamic general-equilibrium model of the Portuguese economy in very general terms. Complete model documentation with detailed descriptions of the model equations, parameters, data, calibration, and numerical implementation, can be found in Pereira and Pereira (2012).

We consider a decentralized economy in a dynamic general-equilibrium framework. All agents are price-takers and have perfect foresight. With money absent, the model is framed in 
real terms. There are four sectors in the economy - the production sector, the household sector, the public sector and the foreign sector. The first three have endogenous behavior, but all four sectors are interconnected through competitive market equilibrium conditions, as well as the evolution of the stock variables and the relevant shadow prices. All markets are assumed to clear.

The trajectory for the economy is described by the optimal evolution of eight stock and five shadow price variables - private capital, wind energy capital, public capital, human capital, and public debt, together with their shadow prices, and foreign debt, private financial wealth, and human wealth. In the long term, endogenous growth is determined by the optimal accumulation of private capital, public capital and human capital. The last two are publicly provided.

\subsection{The Production Sector}

Aggregate output is produced with a Constant Elasticity of Substitution (CES) technology, linking value added and primary energy demand. Value added is produced according to a Cobb-Douglas technology exhibiting constant returns to scale in the reproducible inputs effective labor inputs, private capital, and public capital. Only the demand for labor and the private capital stock are directly controlled by the firm, meaning that, if public investment is absent, then decreasing returns set in. Public infrastructure and the economy-wide stock of knowledge are publicly financed and are positive externalities. Primary energy demand is produced according to a CES technology using crude oil inputs and non-transportation energy sources. The production of non-transportation energy is defined according to a Cobb-Douglas technology using coal, natural gas and wind energy inputs.

Private capital accumulation is characterized by a dynamic equation of motion where physical capital depreciates. Gross investment is dynamic in nature with its optimal trajectory induced by the presence of adjustment costs. These costs are modeled as internal to the firm - a loss in capital accumulation due to learning and installation costs - and are meant to reflect rigidities in the accumulation of capital towards its optimal level. Adjustment costs are assumed 
to be non-negative, monotonically increasing, and strictly convex. In particular, we assume adjustment costs to be quadratic in investment per unit of installed capital.

The firms' net cash flow represents their after-tax position when revenues from sales are netted of wage payments and investment spending. After-tax net revenues reflect the presence of a private investment and wind energy investment tax credits, as well as taxes on corporate profits and Social Security contributions paid by the firms on gross salaries.

Buildings make up a fraction of total private investment expenditure. Only this fraction is subject to value-added and other excise taxes, the remainder is exempt. The corporate income tax base is calculated as revenues from the sale of output, net of total labor costs, and net of fiscal depreciation allowances over past and present capital investments. A straight-line fiscal depreciation method is used, and investment is assumed to grow with output. Under these assumptions, depreciation allowances are simply proportional to the difference of two infinite geometric sums.

Optimal production behavior consists in choosing the levels of investment and labor that maximize the present value of the firms' net cash flows, subject to the equation of motion for private capital accumulation. The demands for labor and investment are obtained from the current-value Hamiltonian function, where the shadow price of private capital evolves according to the respective co-state equation. Finally, with regard to the firm's financial link with the rest of the economy, we assume that at the end of each operating period the net cash flow is transferred back to the households.

\subsection{The Energy Sector}

We consider the introduction of $\mathrm{CO}_{2}$ taxes levied on primary energy purchased by firms. This is consistent with the nature of the existing policy environment in Portugal in which $\mathrm{CO}_{2}$ permits may now be auctioned off to firms. Furthermore, evidence suggests that administrative costs are substantially lower the further upstream the tax is administered. By considering taxation 
at the firm level, the additional costs induced by $\mathrm{CO}_{2}$ taxes are transmitted through the economy in a fashion consistent with the energy content of the different goods. Not levying the $\mathrm{CO}_{2} \operatorname{tax}$ on consumers therefore avoids a double taxation of the carbon content of a good.

The energy sector is an integral component of the firms' optimization decisions. We consider primary energy consumption by firms for crude oil, coal, natural gas and wind energy. Primary energy demand refers to the direct use of an energy vector at the source, in contrast to energy resources that undergo a conversion or transformation process.

Primary energy consumption provides the most direct approach for accounting for $\mathrm{CO}_{2}$ emissions from fossil fuel combustion activities. Carbon is released from fossil fuel upon combustion. Together, the quantity of fuel consumed, its carbon factor, oxidation rate, and the ratio of the molecular weight of $\mathrm{CO}_{2}$ to carbon are used to compute the amount of $\mathrm{CO}_{2}$ emitted from fossil fuel combustion activities in a manner consistent with a reference approach suggested by the Intergovernmental Panel for Climate Change (2006). These considerations suggest a linear relationship between $\mathrm{CO}_{2}$ emissions and fossil fuel combustion activities.

Fossil fuels are hydrocarbons defined by the relative amounts of carbon and hydrogen in each molecule. In the combustion reaction, the compound reacts with an oxidizing element, such as oxygen. Thus, the amount of carbon relative to hydrogen in the fuel will determine the fuel's carbon emissions factor, i.e., the amount of carbon emitted per unit of energy. The molecular weight of carbon dioxide $\mathrm{CO}_{2}$ is $44 / 12$ times greater than the weight of carbon alone (the molecular weight of carbon is 12 and that of oxygen is 16 which give $\mathrm{CO}_{2}$ a weight of 44 moles and carbon of 12 moles). The fuel's $\mathrm{CO}_{2}$ emission factor can be computed from the product of its carbon-emission factor, in tons of oil equivalent, the fraction of carbon oxidized and the ratio of the molecular weight of carbon dioxide to carbon. The relevant computations are given in Table 1. For each ton of oil equivalent consumed, crude oil yields $3.04 \mathrm{tCO}_{2}$, coal yields 3.78 $\mathrm{tCO}_{2}$, and natural gas yields $2.34 \mathrm{tCO}_{2}$. 
Table 1

Carbon Dioxide Emission Factor by Fuel

\begin{tabular}{lcccccc}
\hline \hline Fuel types & Unit & $\begin{array}{c}\text { Conversion } \\
\text { factor } \\
\text { (TJ/Unit) }\end{array}$ & $\begin{array}{c}\text { Carbon } \\
\text { emission } \\
\text { factor } \\
\text { (tC/TJ) }\end{array}$ & $\begin{array}{c}\text { Carbon } \\
\text { content } \\
(\mathbf{G g ~ C )}\end{array}$ & $\begin{array}{c}\text { Fraction of } \\
\text { carbon } \\
\text { oxidized }\end{array}$ & $\begin{array}{c}\text { Actual CO }_{2} \\
\text { emissions } \\
\left(\mathbf{G g} \mathbf{C O}_{2}\right)\end{array}$ \\
\hline Crude Oil & toe & 0.041868 & 20.00 & 0.84 & 0.99 & 3.04 \\
Bituminous Coal & toe & 0.041868 & 25.10 & 1.05 & 0.98 & 3.78 \\
Natural Gas (Dry) & toe & 0.041868 & 15.30 & 0.64 & 1.00 & 2.34 \\
\hline \hline
\end{tabular}

Sources: Intergovernmental Panel for Climate Change (2006) and authors' calculations

Aggregate primary-energy demand is produced with a CES technology, in which crude oil, and non-transportation fuels are substitutable at a rate of less than unity, which reflects the dominance of petroleum products in transportation energy demand, and the ubiquity of coal, natural gas and - to a lesser extent - wind energy, in electric power and industry. Nontransportation fuels are produced with a Cobb-Douglas technology that takes into account the relatively greater potential for substitution in electric power and industry. The accumulation of wind energy infrastructure is governed by a dynamic equation of motion where physical capital wind turbines - depreciates, and investment is subject to adjustment costs, just as in the case of private capital. Wind energy investment decisions are internal to the firm, while coal, natural gas and oil are imported.

Optimal primary energy demand is derived by maximizing the present value of the firms' net cash flows, as discussed above. In turn, the demand for coal and natural gas are defined through the nested dual problem of minimizing energy costs, given the production function and optimal demand for these energy vectors in electric power and industry. Finally, the variational condition for optimal wind energy investment and the equation of motion for the shadow price of wind energy are defined by differentiating the Hamiltonian with respect to wind energy investment and its stock. 


\subsection{The Households}

An overlapping-generations specification was adopted in which the planning horizon is finite but in a non-deterministic fashion. A large number of identical agents are faced each period with a probability of survival. The assumption that the probability of survival is constant over time and across age cohorts yields a perpetual youth specification. Without loss of generality, the population, which is assumed to be constant, is normalized to one. Therefore, per capita and aggregate values are equal.

The household chooses consumption and leisure streams that maximize intertemporal utility, subject to a consolidated budget constraint. The objective function is subjectively discounted lifetime-expected utility. Preferences are additively separable in consumption and leisure, and take on the CES form. A lower probability of survival reduces the effective discount factor, thus making the household relatively more impatient.

The budget constraint reflects a value-added tax on consumption, and states that the households' expenditure stream, discounted at the after-tax market real interest rate, cannot exceed total wealth. The loan rate at which households borrow and lend among themselves is greater than the after-tax interest rate, thus reflecting the probability of survival.

Total wealth is age-specific and is composed of human wealth, net financial worth, and the present value of the firm. Human wealth represents the present discounted value of the household's future labor income stream, net of personal income taxes and workers' social security contributions. The household's wage income is determined by its endogenous decision of how much labor to supply out of a total time endowment, and by the stock of knowledge or human capital that is augmented by public investment in education. Labor earnings are discounted at a higher rate, reflecting the probability of survival.

A household's income increases with net interest payments received on public debt, profits distributed by corporations, international transfers, and also with public transfers. On the spending side, debts to foreigners are serviced, taxes are paid and consumption expenditures are 
made. Income, net of spending, adds to net financial wealth. Under the assumption of no bequests, households are born without any financial wealth. In general, total wealth is agespecific due to age-specific labor supplies and consumption streams.

Assuming a constant real interest rate, the marginal propensity to consume out of total wealth is age-independent and aggregation over age cohorts is greatly simplified. This allows us to write the aggregate demand for leisure as a function of aggregate consumption.

\subsection{The Public Sector}

The equation of motion for public debt reflects the fact that the excess of government expenditures over tax revenues has to be financed with further public debt. Total tax revenues include personal income taxes, corporate income taxes, value-added taxes, and social security taxes levied on firms as well as on workers. All of these taxes are levied on endogenouslydetermined tax bases. Residual taxes are modeled as lump sum, and are assumed to grow at an exogenous rate.

The public sector pays interest to service its public debt, and transfers funds to households in the form of pensions, unemployment subsidies, and social transfers, which grow at an exogenous rate. In addition, it engages in public consumption activities and public investment in both public capital and human capital.

Public investments are determined optimally, respond to economic incentives, and constitute an engine of endogenous growth. The accumulations of human capital and public capital are subject to depreciation and adjustment costs, which are a fraction of the respective investment levels. The adjustment cost functions are strictly convex and quadratic.

Public-sector decisions consist of choosing the trajectories for public consumption, public investment in human capital and public investment in public capital that maximize social welfare, defined as the net present value of the future stream of utility derived from public consumption, parametric on household private consumption-leisure decisions. The optimal 
choice is subject to three constraints, the equations of motion of the stock of public debt, the stock of public capital, and the stock of human capital. The optimal trajectories depend on the shadow prices of public debt, public capital, and human capital stocks, respectively. Optimal conditions are defined for public debt, for public consumption, for public investment, and for investment in human capital.

\subsection{The Foreign Sector}

The equation of motion for foreign financing provides a stylized description of the balance of payments. Domestic production and imports are absorbed by domestic expenditure and exports. Net imports incorporate payments by firms for fossil fuels, and are financed through foreign transfers and foreign borrowing. Foreign transfers are assumed to grow at an exogenous rate. Portugal is modeled as a small, open economy. This means that it can obtain the desired level of foreign financing at a rate which is determined in international financial markets. This is the prevailing rate for all domestic agents.

\subsection{The Intertemporal Market Equilibrium}

The intertemporal path for the economy is described by the behavioral equations, by the equations of motion of the stock and shadow price variables, and by the market equilibrium conditions. The labor-market clearing condition incorporates an exogenous structural unemployment rate. The product market equalizes demand and supply for output. Given the open nature of the economy, part of domestic demand is satisfied through the recourse to foreign production. Finally, equilibrium in the financial market reflects the fact that private capital formation and public indebtedness are financed by household savings and foreign financing.

We define the steady-state growth path as an intertemporal equilibrium trajectory in which all the flow and stock variables grow at the same rate, $g$, while market prices and shadow prices are constant. There are three types of restrictions imposed by the existence of a steady 
state. First, it determines the value of critical production parameters, like adjustment costs and depreciation rates, given the initial capital stocks. These stocks, in turn, are determined by assuming that the observed levels of investment of the respective type are such that the ratios of capital to GDP do not change in the steady state. Second, the need for constant public-debt and foreign debt-to-GDP ratios implies that the steady-state public-account deficit and the current account deficit are a fraction, $g$, of the respective stocks of debt. Finally, the exogenous variables, such as public transfers or international transfers, have to grow at the steady-state growth rate.

\subsection{Dataset, Parameter Specification, and Calibration}

The model is implemented numerically using detailed data and parameters sets. Economic data are from the Statistical Annex of the European Community [European Commission (2014d)], budgetary data are from the Portuguese Ministry of Finance [GPEARI (2014)], and energy and environmental data are from the Portuguese Ministry of Economy

[DGEG (2014)]. The decomposition of the aggregate variables follows the average for the period 2000-2013 for macroeconomic data, as well as for the energy variables. This period was chosen to reflect the most recent available information and to cover several business cycles, thereby reflecting the long-term nature of the model. Public debt and foreign debt, as well as the stocks of capital, reflect the most recent available data, i.e., the end of 2013.

Parameter values are specified in different ways. Whenever possible, parameter values are taken from the available data sources or the literature. This is the case, for example, of the population growth rate, the probability of survival, the share of private consumption in private spending, and the different effective tax rates.

All the other parameters are obtained by calibration; i.e., in a way that the trends of the economy for the period 2000-2013 are extrapolated as the steady-state trajectory. In some cases, the calibration parameters are chosen freely, in that they are not implied by the state-state 
restrictions. Although free, these parameters have to be carefully chosen since their values affect the value of the remaining calibration parameters. Accordingly, they were chosen either using central values or using available data as guidance. For instance, the elasticity of substitution parameters are consistent with those values often applied in climate policy analysis [see, for example, Manne and Richels (1992), Paltsev et al. (2005) and Koetse et al. (2008)]. The remaining calibration parameters are implied by the steady-state restrictions.

\section{On the Effects of the Evolution of Fossil-Fuel Prices}

Fuel prices are important in climate policy due to their impact on $\mathrm{CO}_{2}$ emissions. Fuel prices directly affect emissions through their impact on energy costs and demand, and as drivers in the adoption of new energy-saving technologies. Elevated fossil-fuel prices reduce the demand for energy, and can stimulate energy efficiency and the adoption of renewable energy technologies, leading to a reduction in emissions [see Martinsen et al (2007)]. Relative price levels, however, may favor a greater use of coal in electric power and synthetic fuels in transportation, thus increasing emissions [see van Ruijven and van Vuuren (2009)]. Furthermore, fuel prices also affect emissions, indirectly, through their impact on economic growth and its dynamic feedbacks with energy demand [see van Ruijven and van Vuuren (2009)]. A great deal of empirical research highlights the dynamic relationship between energy prices, consumption and economic growth [see Hamilton (2009), He et al. (2010), Balcilar et al. (2010) and Korhonen and Ledyaeva (2010)].

\subsection{The Fossil-Fuel Price Scenarios}

We consider three scenarios for the evolution of international prices for coal, oil, and natural gas. These fossil-fuel price scenarios are the reference forecasts for the Portuguese Commission for Environmental Tax Reform [see Comissão para a Reforma da Fiscalidade Verde (2014), and Esteves (2014)], and are summarized in Table 2. 
Table 2

Fossil-Fuel Price Scenarios

Units: Price Index $(2013=1.00)$

\begin{tabular}{|c|c|c|c|c|c|}
\hline & 2013 & 2015 & 2020 & 2025 & 2030 \\
\hline \multicolumn{6}{|c|}{ European Commission Forecast (EC) } \\
\hline Crude Oil & 1.00 & 1.10 & 1.32 & 1.36 & 1.38 \\
\hline Coal & 1.00 & 1.17 & 1.17 & 1.25 & 1.25 \\
\hline Natural Gas & 1.00 & 1.12 & 1.52 & 1.43 & 1.61 \\
\hline Crude Oil/Coal Price Ratio & 1.00 & 0.94 & 1.13 & 1.09 & 1.10 \\
\hline Natural Gas/Coal Price Ratio & 1.00 & 0.96 & 1.30 & 1.14 & 1.29 \\
\hline Crude Oil/Natural Gas Price Ratio & 1.00 & 0.98 & 0.87 & 0.95 & 0.86 \\
\hline \multicolumn{6}{|c|}{ Reference Case (REF) } \\
\hline Crude Oil & 1.00 & 1.02 & 1.06 & 1.09 & 1.11 \\
\hline Coal & 1.00 & 1.07 & 1.13 & 1.20 & 1.20 \\
\hline Natural Gas & 1.00 & 1.02 & 1.19 & 1.12 & 1.26 \\
\hline Crude Oil/Coal Price Ratio & 1.00 & 0.95 & 0.94 & 0.91 & 0.93 \\
\hline Natural Gas/Coal Price Ratio & 1.00 & 0.95 & 1.05 & 0.93 & 1.05 \\
\hline Crude Oil/Natural Gas Price Ratio & 1.00 & 1.00 & 0.90 & 0.98 & 0.89 \\
\hline \multicolumn{6}{|c|}{ Futures Market Case (MKT) } \\
\hline Crude Oil & 1.00 & 0.94 & 0.80 & 0.82 & 0.83 \\
\hline Coal & 1.00 & 0.98 & 1.08 & 1.16 & 1.16 \\
\hline Natural Gas & 1.00 & 0.92 & 0.86 & 0.81 & 0.91 \\
\hline Crude Oil/Coal Price Ratio & 1.00 & 0.96 & 0.74 & 0.71 & 0.72 \\
\hline Natural Gas/Coal Price Ratio & 1.00 & 0.94 & 0.82 & 0.70 & 0.78 \\
\hline Crude Oil/Natural Gas Price Ratio & 1.00 & 1.02 & 0.90 & 1.01 & 0.92 \\
\hline
\end{tabular}

The fossil fuel price scenarios are primarily based on two sources: the European Commission (EC) and futures markets - namely the ICE, the Intercontinental Exchange. These two sources differ both in their temporal scope, as well as in the magnitude of the price changes expected in the future. In general, the EC forecasts suggest higher prices than futures markets. The EC forecast is considered independently (scenario EC). A second scenario based on futuresmarket prices through 2020 and growth in subsequent years as forecasted by the EC (scenario MKT) is also considered. The central fuel-price assumptions (reference scenario) are based on an average of the EC forecast and the futures-market data, extended with growth in prices derived from the EC forecast. 
The different fuel price scenarios imply very different relative prices for oil, coal, and natural gas. In the reference scenario, the relative price of coal to natural gas remains relatively unchanged, with oil showing a very slight reduction in price, relative to natural gas. In contrast, in the EC scenario the price of coal falls substantially, relative to natural gas, and the price of oil increases, relative to natural gas. The MKT price scenario depicts substantially different relative price movements, with a large increase in coal prices relative to natural gas, and a large reduction in oil prices relative to natural gas. Natural gas prices grow significantly in the EC scenario, while the reduction in coal prices for the MKT price scenario is relatively modest.

\subsection{On the Effects of Fossil-Fuel Prices - The Reference Scenario}

The details of the energy, environmental, economic, and budgetary effects of the reference fossil fuel price scenario are presented in Table 3.

\section{Energy and Environmental Effects}

The evolution of fossil-fuel prices in international markets suggests that, as fuel prices increase, energy demand will fall.. By 2030 , the demand for fossil fuels is $6.2 \%$ lower than steadystate levels. Changes in relative prices further alter the makeup of the energy sector. The overall increase in the price of fossil fuels, relative to renewable energies, stimulates investment in wind energy. We observe a $16.6 \%$ increase in investment in wind energy, and an increase in the stock of wind energy infrastructures by $9.9 \%$ in 2030 . Similarly, while higher energy prices depress demand across the board, the demand for natural gas and coal fall by substantially more than the demand for crude oil. In relation to steady-state levels, natural gas consumption is $11.0 \%$ lower, coal is $8.3 \%$ lower, and crude oil is $4.5 \%$ lower. The reduction in fossil fuel combustion allows for a $6.1 \%$ reduction in emissions in 2030 , relative to steady-state levels.

\section{Economic Effects}

The macroeconomic impact of fossil fuel prices is fundamentally determined by the total change in energy-system costs, as opposed to the fuel mix in the energy system. Higher fuel 
prices and higher spending on energy inputs have a negative impact on the firms' net cash flow. Accordingly, firms reduce private investment by $1.5 \%$, relative to steady-state levels in 2030 . The reduction in private investment drives down the stock of private capital, which in turn dampens economic growth. Energy price increases have a negative impact on employment as well, reducing employment by $0.4 \%$, relative to steady-state levels in 2050 . The smaller reductions in private capital and employment than in energy consumption suggest that, with growing fuel prices, firms tend to substitute capital and especially labor for energy inputs.

Given the impact of fuel prices on private inputs (which, as discussed below, is mirrored by reductions in public and human capital investment), it is of no surprise that higher fuel prices, driven primarily by higher oil prices, have a negative impact on GDP. In 2030, GDP is $0.5 \%$ below steady-state levels.

The feedback between domestic demand, production and income defines the impact of fuel prices on private consumption and foreign debt. The net effect of this process is a reduction in private consumption of around $1 \%$ in 2030 . Consumption smoothing by households implies that these reductions - as a percent of baseline levels - are relatively constant throughout the model's horizon. In turn, while there is a marginal increase in the value of imported primary energy, the contractionary effects of higher fuel prices translate into a reduction in foreign debt of 8.5 percentage points, relative to steady-state levels by 2030 .

\section{Budgetary Effects}

The reduction in economic activity levels due to higher spending on fossil fuels affects the size of the tax bases, and thereby public-sector tax receipts, leading to a $0.6 \%$ reduction in tax revenue by 2030. These changes are driven primarily by reductions in value-added tax (VAT) receipts. On the expenditure side, the public sector optimally adjusts its spending patterns in response to fuel price variations. Overall public expenditure falls by $2.2 \%$, while public consumption falls by $3.1 \%$. Reductions in public investment activities further reinforce the negative effect of declining private inputs on production activities, and have a negative impact on 
Table 3

On the Energy, Economic and Budgetary Effects of Fossil-Fuel Prices - The Central Scenario

(Percent change with respect to steady state levels)

\begin{tabular}{|c|c|c|c|c|}
\hline & & & & \\
\hline & 2020 & 2025 & 2030 & 2050 \\
\hline \multicolumn{5}{|l|}{ Energy } \\
\hline Total Energy Demand & -2.17 & -3.11 & -3.74 & -6.96 \\
\hline Demand for Fossil Fuels & -3.43 & -4.99 & -6.16 & -11.20 \\
\hline Crude Oil & -2.20 & -3.47 & -4.45 & -8.75 \\
\hline Coal & -4.60 & -9.92 & -8.31 & -15.34 \\
\hline Natural Gas & -7.30 & -6.02 & -10.99 & -16.94 \\
\hline Investment in Wind Energy & 13.46 & 14.61 & 16.60 & 21.51 \\
\hline Wind Energy Infrastructures & 4.98 & 7.54 & 9.94 & 16.98 \\
\hline Carbon Dioxide Emissions from Fossil Fuel Combustion & -3.33 & -5.15 & -6.07 & -11.16 \\
\hline Change as a percent of 1990 levels & -3.99 & -6.49 & -8.03 & -17.98 \\
\hline \multicolumn{5}{|l|}{ Economy } \\
\hline Growth Rate of GDP (Percent Change over Previous Period) & 0.95 & 0.95 & 0.94 & 0.94 \\
\hline GDP & -0.02 & -0.22 & -0.45 & -1.45 \\
\hline Private Consumption & -0.95 & -0.95 & -0.96 & -0.98 \\
\hline Private Investment & -0.81 & -1.14 & -1.47 & -2.74 \\
\hline Private Capital & -0.20 & -0.42 & -0.67 & -1.81 \\
\hline Imported Energy & 4.23 & 5.47 & 6.92 & 11.96 \\
\hline Foreign Debt & -3.64 & -6.09 & -8.45 & -15.89 \\
\hline \multicolumn{5}{|l|}{ Labor Markets } \\
\hline Employment & 0.34 & 0.24 & 0.12 & -0.38 \\
\hline Wages & -0.46 & -0.58 & -0.71 & -1.28 \\
\hline \multicolumn{5}{|l|}{ Public Sector } \\
\hline Public Debt & -2.29 & -3.80 & -5.24 & -9.62 \\
\hline Public Expenditures & -2.10 & -2.13 & -2.16 & -2.25 \\
\hline Public Consumption & -3.22 & -3.18 & -3.13 & -2.92 \\
\hline Public Investment & -0.66 & -0.97 & -1.29 & -2.54 \\
\hline Investment in Human Capital & -0.49 & -0.55 & -0.60 & -0.80 \\
\hline Public Capital & -0.19 & -0.42 & -0.67 & -1.84 \\
\hline Human Capital & -0.03 & -0.06 & -0.08 & -0.20 \\
\hline Tax Revenues & -0.33 & -0.47 & -0.64 & -1.30 \\
\hline Personal Income Tax (IRS) & -0.22 & -0.61 & -1.04 & -2.63 \\
\hline Corporate Income Tax (IRC) & 0.16 & -0.04 & -0.29 & -1.42 \\
\hline Value Added Tax (IVA) & -1.02 & -1.08 & -1.13 & -1.34 \\
\hline Social Security Contributions (TSU) & -0.15 & -0.39 & -0.68 & -1.86 \\
\hline
\end{tabular}

economic performance. Overall, despite tax revenue losses, the reduction in expenditure levels lowers the public-debt-to-GDP ratio in 2030 by 5.2 percentage points relative to steady state levels. The optimal government response to the growing opportunity cost of public funds is 
Table 4

On the Effects of Fossil-Fuel Prices - Alternative Price Scenarios

(Percent change with respect to steady-state levels)

\begin{tabular}{|c|c|c|c|c|}
\hline & 2020 & 2025 & 2030 & 2050 \\
\hline \multicolumn{5}{|l|}{ Fossil Fuel Price Scenario: EC } \\
\hline Carbon Dioxide Emissions & -9.36 & -11.80 & -12.75 & -17.93 \\
\hline GDP & -0.58 & -1.07 & -1.48 & -2.93 \\
\hline Labor Demand & 0.41 & 0.17 & -0.03 & -0.75 \\
\hline Foreign Debt & -7.19 & -11.01 & -14.39 & -24.25 \\
\hline Public Debt & -4.24 & -6.50 & -8.49 & -14.18 \\
\hline \multicolumn{5}{|l|}{ Fossil-Fuel Price Scenario: Central } \\
\hline Carbon Dioxide Emissions & -3.33 & -5.15 & -6.07 & -11.16 \\
\hline GDP & -0.02 & -0.22 & -0.45 & -1.45 \\
\hline Labor Demand & 0.34 & 0.24 & 0.12 & -0.38 \\
\hline Foreign Debt & -3.64 & -6.09 & -8.45 & -15.89 \\
\hline Public Debt & -2.29 & -3.80 & -5.24 & -9.62 \\
\hline \multicolumn{5}{|l|}{ Fossil Fuel Price Scenario: MKT } \\
\hline Carbon Dioxide Emissions & 5.29 & 4.55 & 3.63 & -1.38 \\
\hline GDP & 0.60 & 0.73 & 0.70 & 0.19 \\
\hline Labor Demand & 0.27 & 0.32 & 0.29 & 0.02 \\
\hline Foreign Debt & 0.36 & -0.57 & -1.78 & -6.52 \\
\hline Public Debt & -0.08 & -0.76 & -1.56 & -4.48 \\
\hline
\end{tabular}

instrumental in driving positive budgetary effects. Absent these, the tax bases contract and public debt levels rise.

\subsection{On the Effects of Fossil Fuel Prices - Alternative Price Scenarios}

The two alternative price scenarios yield markedly different environmental, economic and budgetary outcomes when compared to the reference scenario. Details are presented in Table 4. The EC price scenario with higher fossil-fuel prices and increasing oil prices, relative to gas, produce substantially larger reductions in emissions, together with more substantial employment and output losses. In turn, these greater contractionary effects translate into smaller levels of foreign debt and public debt. In contrast, the MKT price scenario, with lower fuel prices and a lower price of oil, relative to natural gas, leads to the opposite effects: higher emissions, and larger employment and output gains. Foreign debt is only marginally improved over the status 
quo, as the better terms for imported fossil fuels are accompanied by greater imports of other goods and services. Public debt falls, but again to much less than in the reference case.

\section{On the Effects of Energy Efficiency Improvements}

The direct effect of improved energy efficiency is a reduction in fuel requirements to satisfy a particular level of demand for energy services - i.e., a reduction of production costs and fuel consumption. Indirectly, this boosts firms' net cash flow, as well as and families' disposable income, thereby stimulating demand. In addition, because energy resources are more productive, in that energy services can be provided at a lower cost, relative to other inputs, businesses and corporations have the incentive to shift their input structure towards a greater relative utilization

of energy resources. Furthermore, energy-intensive industries will benefit more from the reduction in energy system costs, generating the potential for structural changes in the economy.

These factors contribute to a behavioral response that limits the reduction in fuel consumption associated with energy efficiency improvements, which is typically referred to as a rebound in energy consumption. This rebound effect has gained increasing attention in recent years [see for example Saunders, 1992, 2000, 2008; Khazzoom, 1980; Brookes, 1990; Grepperud and Rasmussen, 2004; Hanley et al. 2006; Allan et al, 2007; Barker et al., 2007; Hanley et al, 2009; Turner, 2009; and Wei, 2010].

\subsection{On the Potential for Energy Efficiency Gains}

Improving energy efficiency is widely regarded as a key mechanism for lowering the energy intensity and carbon intensity of the economy. Energy efficiency goals have been formalized in a number of EU directives. Most notable is EC Directive 2009/28/EC, which sets a legally binding target of increasing energy efficiency by $20 \%$ by 2020 , relative to 1990 levels, and the current working targets of energy efficiency gains in primary energy consumption of $21 \%$ by 2030 compared to 2007 levels [see, for example, European Commission (2013), 
(2014b)]. These targets imply an increase in energy efficiency of around 1\% each year. Recent legislation and discussions in the EU seem to suggest much more ambitious targets. They point to a $20 \%$ reduction in primary energy use in 2020 , relative to projections made in 2007 , and to a reduction of $40 \%$ in 2030 , relative to 1990 , as a follow up to the existing $20 \%$ target for 2020 [see, for example, European Economy (2014b)]. In both cases, the average annual gain in energy efficiency over the next twenty years would have to be closer to $2 \%$.

An analysis of the Portuguese energy system using the TIMES_PT model [see Seixas and Fortes (2014)] suggests that autonomous energy efficiency improvements equivalent to an average annual savings in primary energy consumption of 2.5\% per year between 2015 and 2030 are cost-effective at 2010 energy prices in the absence of climate policy. This means that there are technologies available which are in the best interest of the economic agents to adopt, based on cost considerations, independent of environmental concerns or public incentives.

In terms of buildings, both residential and industrial, these technologies include the use of more efficient equipment such as LED lighting, as well as thermal-integrity heat pumps and windows Efficiency gains in transportation stem from the widespread use of increasinglyefficient hybrid vehicles and, at a later date, through a widespread use of electric vehicles. Finally, a greater reliance on natural gas in industrial furnaces in place of fuel oil or biomass, and an increasing use of co-generation can reduce energy use.

For the purpose of this study, we consider three scenarios: a reference scenario of an annual gain in energy efficiency of $2 \%$, a low scenario of $1.5 \%$, and a high scenario of $2.5 \%$. As presented above, the reference scenario of $2 \%$ is in line with the discussions on the matter in the EU. It is also consistent with the fact that, with just 57 measures in energy efficiency enacted from 1990 to 2011, Portugal ranks 18 in the EU in terms of the numbers of measures, while Spain leads the group of 28 countries, with 133 measures [see, for example, European Commission (2014e)]. This suggests that Portugal has significant room for improvement. 


\subsection{On the Effects of Energy Efficiency - An Annual Gain of 2\%}

The environmental, economic and budgetary effects of exogenous energy efficiency improvements of $2 \%$ per year are presented in Table 5.

\section{Energy and Environmental Effects}

With exogenous improvements in energy efficiency, relative to the steady state, emissions in 2030 fall by 10.3 percentage points (p.p.) more than in the central fossil-fuel price scenario alone. The improvements in efficiency are not biased in favor of specific energy inputs, as we observe a reduction in energy demand across the board. Overall energy demand declines by a further 10.4 p.p. and the demand for fossil fuels is an additional 10.3 p.p. lower. Similarly, an increase in energy efficiency reduces investment in wind energy by 14.2 p.p. in 2030.

These effects contrast with the effects of the evolution of fossil fuel prices discussed above. In that case, the $6.1 \%$ reduction in emissions was due to a milder reduction in demand for fossil fuels, together with a substantial increase in investment in wind energy. Overall, energy demand is only by $3.7 \%$ lower in 2030 .

It is worth mentioning that energy efficiency improvements are projected to have substantial rebound effects. By lowering energy costs, they decrease energy demand, by less than they would otherwise. Indeed, the annual energy efficiency gain of $2 \%$ would, ceteris paribus, lead to a reduction in energy demand of 31.9 percentage points by 2030 . Nonetheless, we project a decline of only 10.3 percentage points. This means that the rebound effect is about two-thirds of the potential overall effect of energy efficiency improvements.

\section{Economic Effects}

Improved energy efficiency of this nature increases the marginal productivity of energy inputs to production. This lowers production costs and stimulates economic activity. Indeed, we observe that energy efficiency improvements have a positive impact on employment and output. Simulation results suggest that an exogenous improvement in energy efficiency of $2 \%$ per year through 2020 increases GDP by 0.9 p.p. relative to the reference fuel price scenario in 2030 . This 
Table 5

On the Energy, Economic and Budgetary Effects of Energy Efficiency Improvements - An Annual Gain of 2\%

(Under the central fossil-fuel price scenario)

\begin{tabular}{|c|c|c|c|c|}
\hline & \multicolumn{4}{|c|}{ (Percent change with respect to steady-state levels) } \\
\hline & 2020 & 2025 & 2030 & 2050 \\
\hline \multicolumn{5}{|l|}{ Energy } \\
\hline Total Energy Demand & -7.65 & -9.72 & -10.37 & -9.94 \\
\hline Demand for Fossil Fuels & -7.95 & -9.86 & -10.32 & -9.49 \\
\hline Crude Oil & -7.98 & -9.96 & -10.47 & -9.75 \\
\hline Coal & -8.00 & -9.47 & -10.16 & -9.05 \\
\hline Natural Gas & -7.77 & -9.88 & -9.86 & -8.88 \\
\hline Investment in Wind Energy & -16.26 & -15.18 & -14.16 & -12.83 \\
\hline Wind Energy Infrastructures & -6.00 & -8.92 & -10.64 & -12.45 \\
\hline Carbon Dioxide Emissions from Fossil-Fuel Combustion & -7.96 & -9.85 & -10.33 & -9.50 \\
\hline Change relative to 1990 levels & -9.53 & -12.40 & -13.67 & -15.31 \\
\hline \multicolumn{5}{|l|}{ Economy } \\
\hline Growth Rate of GDP (Percent Change over Previous Period) & 1.03 & 1.00 & 0.98 & 0.96 \\
\hline GDP & 0.37 & 0.69 & 0.91 & 1.35 \\
\hline Private Consumption & 0.96 & 0.96 & 0.96 & 0.97 \\
\hline Private Investment & 1.63 & 1.77 & 1.82 & 2.00 \\
\hline Private Capital & 0.51 & 0.85 & 1.12 & 1.71 \\
\hline Imported Energy & -8.56 & -10.93 & -11.75 & -11.97 \\
\hline Foreign Debt & 3.29 & 4.82 & 5.90 & 8.23 \\
\hline \multicolumn{5}{|l|}{ Labor Markets } \\
\hline Employment & -0.14 & 0.03 & 0.14 & 0.34 \\
\hline Wages & 0.75 & 0.96 & 1.08 & 1.26 \\
\hline \multicolumn{5}{|l|}{ Public Sector } \\
\hline Public Debt & 1.84 & 2.69 & 3.29 & 4.55 \\
\hline Public Expenditures & 1.94 & 1.92 & 1.92 & 1.93 \\
\hline Public Consumption & 2.81 & 2.73 & 2.69 & 2.60 \\
\hline Public Investment & 1.45 & 1.61 & 1.69 & 1.93 \\
\hline Investment in Human Capital & 0.40 & 0.44 & 0.47 & 0.58 \\
\hline Public Capital & 0.55 & 0.91 & 1.18 & 1.73 \\
\hline Human Capital & 0.03 & 0.05 & 0.07 & 0.15 \\
\hline Tax Revenues & 0.55 & 0.77 & 0.91 & 1.17 \\
\hline Personal Income Tax (IRS) & 0.46 & 1.01 & 1.38 & 2.05 \\
\hline Corporate Income Tax (IRC) & 0.17 & 0.68 & 1.02 & 1.61 \\
\hline Value Added Tax (IVA) & 1.14 & 1.16 & 1.17 & 1.20 \\
\hline Social Security Contributions (TSU) & 0.64 & 1.04 & 1.29 & 1.75 \\
\hline
\end{tabular}


Table 6

On the Effects of Energy Efficiency - Alternative Scenarios

(Under the central fossil-fuel price scenario)

\begin{tabular}{lcccc}
\hline \hline & (Percent change with respect to steady-state levels) \\
\hline Annual Energy Efficiency Improvements: $\mathbf{1 . 5 \%}$ & $\mathbf{2 0 2 0}$ & $\mathbf{2 0 2 5}$ & $\mathbf{2 0 3 0}$ & $\mathbf{2 0 5 0}$ \\
Carbon Dioxide Emissions & & & & \\
GDP & -6.14 & -7.65 & -8.04 & -7.38 \\
Labor Demand & 0.29 & 0.54 & 0.71 & 1.05 \\
Foreign Debt & -0.11 & 0.02 & 0.11 & 0.27 \\
Public Debt & 2.57 & 3.77 & 4.63 & 6.45 \\
Annual Energy Efficiency Improvements: $\mathbf{2 . 0 \%}$ & 1.44 & 2.11 & 2.57 & 3.56 \\
Carbon Dioxide Emissions & & & & \\
GDP & -7.96 & -9.85 & -10.33 & -9.50 \\
Labor Demand & 0.37 & 0.69 & 0.91 & 1.35 \\
Foreign Debt & -0.14 & 0.03 & 0.14 & 0.34 \\
Public Debt & 3.29 & 4.82 & 5.90 & 8.23 \\
Carbon Dioxide Emissions & 1.84 & 2.69 & 3.29 & 4.55 \\
GDP & & & & \\
Labor Demand & -9.68 & -11.90 & -12.46 & -11.47 \\
Foreign Debt & 0.45 & 0.84 & 1.10 & 1.62 \\
Public Debt & -0.17 & 0.04 & 0.16 & 0.41 \\
\hline Annual Energy Efficiency Improvements: $\mathbf{2 . 5 \%}$ & 3.95 & 5.78 & 7.08 & 9.87 \\
\hline \hline
\end{tabular}

change in economic performance is induced by a shift into a more capital-intensive economy, as investment increases 1.8 p.p. while employment increases just by 0.1 p.p..

Finally, energy efficiency leads to a 1.0 p.p. increase in private consumption. Despite the increase in domestic output and a marginal decline in the value of energy imports, the increase in domestic demand leads to an increase in foreign indebtedness by about 5.9 p.p. in 2030.

\section{Budgetary Effects}

The subsequent expansions in the tax base lower the opportunity cost of public funds and public expenditures increase substantially as a result, negatively affecting public sector accounts. The increase in economic activity levels due to the energy efficiency improvements enlarges the tax bases and raises tax revenues across the board. Tax revenues increase by 0.9 p.p. in 2030 , led by a 1.4 p.p. increase in the personal income tax. On the other side of the public budget, however, public expenditures increase even more by 1.9 p.p. in 2030, led mostly by an 
increase of 2.7 p.p. in public consumption. Accordingly, we observe an increase in public indebtedness over time leading to an increase in the debt-to-GDP ratio of 3.3 p.p. in 2030.

\subsection{On the Effects of Energy Efficiency - Alternative Scenarios}

The two alternative scenarios for energy efficiency improvements lead to changes in the environmental, economic and budgetary outcomes that accentuate the effects observed in the central scenario without changing their nature. Higher efficiency gains leads to greater gains in terms of emission reductions and output gains, but also larger public and foreign indebtedness. Details are presented in Table 6.

\section{On the Effects of Carbon Taxation}

Carbon taxation has gained momentum as an important part of a package of policy instruments for reducing greenhouse gas emissions in a cost-effective manner. In particular, we have witnessed a generalized growing concern over mounting public debt in recent years and the need to promote fiscal sustainability. $\mathrm{CO}_{2}$ taxes and auctioned emissions permits have emerged as potentially important instruments for increasing public revenues (see, for example, Metcalf and Weisbach 2008; Galston and MacGuineas 2010; Metcalf 2009, 2010 and Nordhaus 2010).

$\mathrm{A} \mathrm{CO}_{2}$ tax works primarily through two mechanisms. First, by affecting relative prices, the $\mathrm{CO}_{2}$ tax drives changes to the firms' input structure that affects the marginal productivity of factor inputs. Second, the $\mathrm{CO}_{2}$ tax increases energy expenditure and reduces the firms' net cash flow, household income and domestic demand. These substitution and scale effects are central in understanding how carbon taxation affects energy consumption, emissions, economic performance and the public sector account.

\subsection{On the Level of Carbon Taxation}

The choice of how high the carbon tax should be is a delicate matter. There are now about fifteen countries which have introduced - or are about to introduce - carbon taxes. The 
levels and scope of taxation vary widely from a low of about $1.5 €$ per ton of $\mathrm{CO}_{2}$ in Japan and about $7 €$ per ton in Iceland - covering $50 \%$ and $70 \%$ of domestic emissions respectively, to near $115 €$ in the United Kingdom and $125 €$ in Sweden, although these cover only about $25 \%$ of total emissions in these countries. In about two-thirds of the countries, taxes range from $10 €$ to $35 €$ per ton of $\mathrm{CO}_{2}$ and cover between $35 \%$ and $70 \%$ of emissions, [for details, see, for example, World Bank (2014)].

Another reference point for the price of carbon emissions is given by the European Trading System (ETS). The average price for $\mathrm{CO}_{2}$ emissions allowances observed in the EU-ETS between 2006 and 2011 was $15 €$ per ton. During this period, the price of carbon reached a maximum of $34 €$. Prices, however, have shown a great degree of volatility. In particular, the price of carbon fell substantially over weak demand to $8 €$ per $\mathrm{tCO}_{2}$ in 2012, to $4.7 €$ in 2013 and to an average of just under $6.0 €$ in 2014 . More importantly, from our perspective, $15 €$ is the average reference price for the sectors covered by the EU-ETS for the period from 2015 to 2030 [see, for example, European Commission (2014e)] with the price of carbon increasing from the current low levels to $35 €$ in 2030 .

Given this evidence, we have chosen as the reference point in this study a tax of 15 Euro per $\mathrm{tCO}_{2}$. This tax level is also consistent with the recommendation in a recent report by the European Environmental Agency [see Anderson et al. (2013)] and is also indicative of the efforts required to meet domestic targets [see Pereira and Pereira (2013)]. We further consider a lower tax level of $5 €$ per ton and a higher level of $35 €$ per ton. This way we cover, in broad terms, the bulk of the tax levels observed all over the world, as well as the boundaries of the current ETS price levels and the levels projected for 2030.

It should be pointed out that, in order to evaluate the full potential for carbon pricing policies in the Portuguese economy, we assume that every sector of the economy is subject to the tax. This assumption is consistent with the introduction of a $\mathrm{CO}_{2} \operatorname{tax}$ in sectors not covered by the EU-ETS and auctioning permits for those firms participating in the EU-ETS. In this way, 
firms and sectors not covered by the EU-ETS will face a price signal reflecting the costs of carbon through the tax, while those firms and sectors participating in the EU-ETS will face this price signal in the market. Although the current market price for carbon is substantially below $15 €$ per $\mathrm{tCO}_{2}$, adjustments to the cap and projections undertaken for the EU between 2015 and 2030 both suggest, as indicated above, an average value of $15 €$ per $\mathrm{tCO}_{2}$.

\subsection{On the Effects of a Carbon Tax of $15 €$ per tCO2}

The effect of a $15 €$ per $\mathrm{tCO}_{2}$ tax on energy demand, emissions, economic performance and the public sector account are presented in Table 7.

\section{Energy and Environmental Effects}

The $\mathrm{CO}_{2}$ tax increases the price of fossil fuels relative to renewable energy resources, and changes the relative price of the different fossil fuels to reflect their carbon content. This has a profound impact on the energy sector, driving a reduction in fossil-fuel consumption of 5.3 p.p. and an increase in investment in wind energy infrastructure of 12.0 p.p. by 2030 The impact of $\mathrm{CO}_{2}$ taxation on aggregate fossil fuel demand, however, masks important changes in the fuel mix. In particular, we observe a 23.9 p.p. reduction in coal consumption while crude oil falls by 5.7 p.p. and natural gas by 2.0 p.p.. As such, the $\mathrm{CO}_{2}$ tax sets in motion a shift in the energy mix which favors wind energy at the expense of coal. Overall, by 2030, total energy demand declines by 5.3 p.p. and $\mathrm{CO}_{2}$ emissions decline by 9.1 p.p..

\section{Economic Effects}

By increasing energy system costs, $\mathrm{CO}_{2}$ taxation has a negative impact on the firms' net cash flow, which limits the firms' demand for inputs. Employment falls by 0.4 p.p. in 2030, less than the reduction in private investment of 1.6 p.p., and substantially less than the drop in fossil fuel demand. This is consistent with an overall reduction in input levels coupled with a shift in the firms' input structure away from energy inputs and towards a more labor-intensive economy. Given the reductions in factor demand, it is of no surprise that $\mathrm{CO}_{2}$ taxation has a negative 
impact on economic activity levels, lowering GDP in 2030 by 1.0 p.p. relative to the fuel price and efficiency scenarios.

The reduction in the firms' net cash flow has a direct impact on household income, since it is an integral part of total wealth. This lowers private consumption by 0.4 p.p. In turn, by 2030 , fossil fuel imports are 7.2 p.p. lower. The reduction in domestic demand, coupled with the reduced expenditure on imported energy resources stemming from demand adjustments, suggests that foreign debt levels fall by 3.4 p.p. in 2030.

\section{Budgetary Effects}

The carbon tax strengthens fiscal consolidation. Simulation results suggest that a tax of $15 €$ per $\mathrm{tCO}_{2}$ has a neutral effect on the public debt by 2030 , and a favorable effect of marginally reducing the public debt thereafter. These positive effects are fundamentally due to reductions in

public expenditures, but are also due to the higher revenues associated with the introduction of the carbon tax.

On the revenue side, a reduction in income, consumption and private inputs results in contracting tax bases. Accordingly, we observe lower personal income tax, corporate income tax, and value-added tax revenues, as well as, lower social security contributions. These reductions are clearly offset by the $\mathrm{CO}_{2}$ tax receipts. As a result, total tax revenue is 0.1 p.p. greater in 2030 . On the expenditure side, and considering an appropriate policy response to high levels of public indebtedness, public expenditures fall by 1.5 p.p. in 2030. This increase reflects a shift in public expenditure from consumption to investment. Public consumption falls by 2.0 p.p. while public capital investment and human capital investment fall 1.5 p.p. and 0.4 p.p., respectively. The drop in public investment is again consistent with shifts in the firms' production structure towards labor. 
Table 7

On the Effects of a Carbon Tax of $15 €$ per tCO2

(Under the central fossil-fuel price scenario and annual energy efficiency gains of $2 \%$ )

(Percent change with respect to steady-state levels)

\begin{tabular}{|c|c|c|c|c|}
\hline & 2020 & 2025 & 2030 & 2050 \\
\hline \multicolumn{5}{|l|}{ Energy } \\
\hline Total Energy Demand & -6.26 & -5.50 & -5.32 & -4.60 \\
\hline Demand for Fossil Fuels & -8.78 & -8.25 & -8.19 & -7.31 \\
\hline Crude Oil & -5.94 & -5.74 & -5.65 & -5.23 \\
\hline Coal & -26.38 & -23.47 & -23.88 & -20.46 \\
\hline Natural Gas & -1.75 & -2.45 & -1.98 & -1.92 \\
\hline Investment in Wind Energy & 16.55 & 13.50 & 12.03 & 10.11 \\
\hline Wind Energy Infrastructures & 8.00 & 10.10 & 10.90 & 10.75 \\
\hline Carbon Dioxide Emissions from Fossil Fuel Combustion & -9.76 & -9.10 & -9.07 & -8.06 \\
\hline Change relative to 1990 levels & -11.70 & -11.45 & -11.99 & -12.99 \\
\hline \multicolumn{5}{|l|}{ Economy } \\
\hline Growth Rate of GDP (Percent Change over Previous Period) & 0.99 & 0.97 & 0.96 & 0.95 \\
\hline GDP & -0.70 & -0.87 & -0.98 & -1.21 \\
\hline Private Consumption & -0.36 & -0.36 & -0.35 & -0.32 \\
\hline Private Investment & -1.68 & -1.62 & -1.58 & -1.58 \\
\hline Private Capital & -0.67 & -0.95 & -1.14 & -1.46 \\
\hline Imported Energy & -7.17 & -7.14 & -7.16 & -7.23 \\
\hline Foreign Debt & -1.87 & -2.74 & -3.36 & -4.65 \\
\hline \multicolumn{5}{|l|}{ Labor Markets } \\
\hline Employment & -0.27 & -0.34 & -0.40 & -0.50 \\
\hline Wages & -0.71 & -0.78 & -0.82 & -0.86 \\
\hline \multicolumn{5}{|l|}{ Public Sector } \\
\hline Public Debt & -0.86 & -1.25 & -1.52 & -2.03 \\
\hline Public Expenditures & -1.52 & -1.50 & -1.49 & -1.48 \\
\hline Public Consumption & -2.11 & -2.07 & -2.04 & -1.97 \\
\hline Public Investment & -1.52 & -1.49 & -1.49 & -1.55 \\
\hline Investment in Human Capital & -0.34 & -0.36 & -0.38 & -0.46 \\
\hline Public Capital & -0.75 & -1.03 & -1.20 & -1.47 \\
\hline Human Capital & -0.02 & -0.04 & -0.06 & -0.12 \\
\hline Tax Revenues & 0.34 & 0.21 & 0.13 & -0.02 \\
\hline Personal Income Tax (IRS) & -0.74 & -1.01 & -1.19 & -1.52 \\
\hline Corporate Income Tax (IRC) & -0.67 & -0.93 & -1.11 & -1.42 \\
\hline Value Added Tax (IVA) & -0.65 & -0.63 & -0.62 & -0.60 \\
\hline Social Security Contributions (TSU) & -1.00 & -1.16 & -1.27 & -1.49 \\
\hline
\end{tabular}


Table 8

On the Effects of a Carbon Tax - Alternative Scenarios

(Under the central fossil-fuel price scenario and annual energy efficiency gains of $2 \%$ )

(Percent change with respect to steady-state levels)

\begin{tabular}{|c|c|c|c|c|}
\hline & 2020 & 2025 & 2030 & 2050 \\
\hline \multicolumn{5}{|l|}{$\mathrm{CO} 2 \mathrm{Tax}$ of $5 €$ per tCO2 } \\
\hline Carbon Dioxide Emissions & -3.91 & -3.60 & -3.59 & -3.13 \\
\hline GDP & -0.24 & -0.30 & -0.34 & -0.42 \\
\hline Labor Demand & -0.10 & -0.12 & -0.14 & -0.18 \\
\hline Foreign Debt & -0.65 & -0.95 & -1.17 & -1.61 \\
\hline Public Debt & -0.30 & -0.43 & -0.52 & -0.69 \\
\hline \multicolumn{5}{|l|}{$\mathrm{CO} 2$ Tax of $15 €$ per tCO2 } \\
\hline Carbon Dioxide Emissions & -9.76 & -9.10 & -9.07 & -8.06 \\
\hline GDP & -0.70 & -0.87 & -0.98 & -1.21 \\
\hline Labor Demand & -0.27 & -0.34 & -0.40 & -0.50 \\
\hline Foreign Debt & -1.87 & -2.74 & -3.36 & -4.65 \\
\hline Public Debt & -0.86 & -1.25 & -1.52 & -2.03 \\
\hline \multicolumn{5}{|l|}{ CO2 Tax of $35 €$ per tCO2 } \\
\hline Carbon Dioxide Emissions & -17.69 & -16.70 & -16.62 & -15.07 \\
\hline GDP & -1.51 & -1.89 & -2.15 & -2.66 \\
\hline Labor Demand & -0.58 & -0.73 & -0.85 & -1.10 \\
\hline Foreign Debt & -4.10 & -6.01 & -7.38 & -10.25 \\
\hline Public Debt & -1.89 & -2.76 & -3.37 & -4.52 \\
\hline
\end{tabular}

\subsection{On the Effects of a Carbon Tax - Alternative Scenarios}

The two alternative carbon tax scenarios lead to changes in the environmental, economic and budgetary outcomes that accentuate the effects observed in the central scenario without changing their nature. Higher carbon taxes lead to greater gains in terms of emissions reductions, but also larger losses in terms of output and employment, and greater reductions in foreign and public debt. Details are presented in Table 8.

\section{On the Relative Roles of Fossil Fuel Prices, Energy Efficiency, and Carbon Taxes}

We have identified important and clearly differentiated environmental, economic and budgetary effects associated with each of the three drivers of reductions in carbon emissions, the evolution of international fossil fuel prices, energy efficiency gains, and carbon taxation. Here we 
consider the overall picture on how these three mechanisms put together contribute to achieving emission targets and their economic and budgetary effects. Results are presented in Table 9.

\subsection{Carbon Dioxide Emissions}

In terms of emissions, we show that, by 2030, changing fossil fuel prices under the reference-price scenario leads to a reduction of $6.1 \%$ in $\mathrm{CO}_{2}$ emissions relative to steady-state levels, while an increase in energy efficiency of $2 \%$ leads to an additional 10.3 p.p. reduction and a tax of $15 €$ per $\mathrm{tCO}_{2}$ to a reduction of 9.1 p.p. all relative to baseline levels. Behind these reductions in emissions are important and differentiated changes in the energy sector. In the fuel-price scenario, there is a significant reduction in the demand for natural gas, in the case of the carbon tax reductions in emissions come with a sharp reduction in coal, and in the case of energy efficiency - by design - there is an even reduction in all fossil fuels. In turn, the increase in investment in wind energy under the carbon tax, although not as pronounced as in the reference price scenario contrasts, with the sharp decline observed in the efficiency scenario.

The combined effect of these policies in terms of emissions reduction is approximately $25.4 \%$ of the projected baseline emissions in 2030 , which corresponds to $33.7 \%$ of the emissions in 1990. To achieve a higher reduction in emissions vis-à-vis the 1990 levels more in line with the current targets, and given the reference price scenario - which naturally the domestic authorities cannot control - would require a greater effort in either the energy efficiency or carbon tax margins, or both. Indeed, for example, we project that under the reference-price scenario the combined effects of a greater achievement in energy efficiency of $2.5 \%$ and a carbon tax of $35 €$ per $\mathrm{tCO}_{2}$ would lead to a combined reduction of $35.2 \%$ in 2030 relative to the baseline emissions, which corresponds to about 45\% of the emissions in 1990.

To be sure, the evolution of the international fossil fuel prices in late 2014 and the first half of 2015 is a further complicating factor. The actual revolution of fossil-fuel prices has been much closer to the MKT price scenario than any of the other two. The implication is that the 
Table 9

Summary of the Relative Roles of

Fossil-Fuel Prices, Energy Efficiency Improvements, and Carbon Taxation

(Under their respective central cases)

(Percent change with respect to steady-state levels)

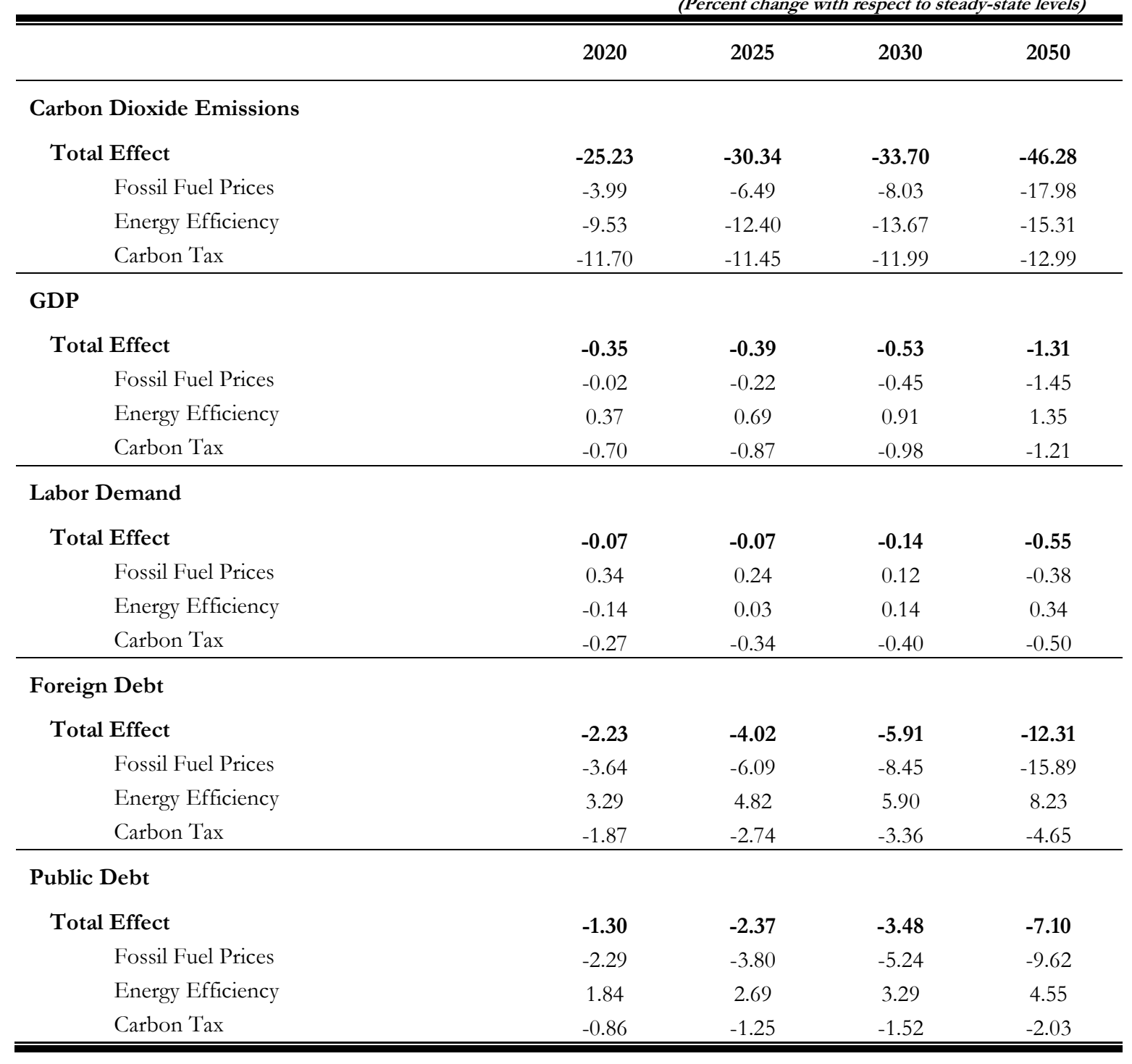

reference price scenario is likely to be overly optimistic in terms of the impact of fossil-fuel prices on domestic carbon emissions. Accordingly, the levels of carbon taxation needed to achieve the stated emission goals are likely to be higher than $35 €$ per $\mathrm{tCO}_{2}$ as achieving even greater gains in energy efficiency does not seem a reasonable expectation. 


\subsection{Economic Effects}

The economic impacts of these three different drivers are different in very significant ways. We show that, together, the evolution of fuel prices and of a new carbon tax lead to contractions in economic activity, reductions of $0.5 \%$ and $1.0 \%$ by 2030 , respectively - while the increase in energy efficiency has an expansionary effect, yielding a $0.9 \%$ increase in GDP by 2030. The combined effect of these three drivers - and therefore the economic cost of the reduction in emissions presented above - is a reduction of $0.5 \%$ in GDP by 2030.

The reductions induced by the carbon tax and by the evolution of fossil fuel prices come with an overall reduction in input demands, and with a shift into a more capital-intensive economy in the former, and a more labor-intensive one in the latter. In turn, the improvement in economic performance with energy efficiency is induced by a shift into a more capital-intensive economy, but with a substantial increase in investment activities together with a decline in employment.

In terms of domestic demand, a new carbon taxes but particularly fossil fuel prices drive down private consumption while energy efficiency leads to a very substantial increase. In turn, energy efficiency and the new carbon tax lead to a decline in the value of energy imports while evolution of fuel prices leads to an increase. However, the overall contraction in domestic demand under the fossil fuel prices and carbon tax lead reductions of foreign debt, particularly significant in the first case, while with energy efficiency the expanded domestic demand lead to an increase in foreign debt. Overall, the combined effect of the three drivers is a $5.9 \%$ reduction in foreign debt by 2030 .

From the perspective of the economic impacts, it is clear that, although both mechanisms are necessary, domestic energy policy should focus more on promoting efficiency than on carbon taxation, or - at the very least - use both, hand in hand. A greater share of emissions reductions obtained through energy efficiency would mitigate the negative economic effects we observe. Given our projections, there is enough margin to increase efforts to 
encourage energy efficiency improvements without jeopardizing the favorable outcome of the combined policies on the evolution of foreign debt.

\subsection{Budgetary Effects}

Finally, the budgetary impacts of these three different drivers are also very different. With greater energy efficiency, we observe an increase in public indebtedness of $3.3 \%$ in 2030 with both public spending and tax revenues increasing. This is opposite of the response to higher fossil fuel prices, where public debt declines by $5.2 \%$ with both public spending and public revenues shrinking. The carbon tax reduces public debt by $1.5 \%$ by 2030 . These effects come from both reductions in public expenditures and increases in tax revenues. The combined decline in public indebtedness induced by the three drivers is $3.5 \%$ by 2030 .

From the perspective of the budgetary effects of these drivers, we find that once again although energy efficiency has undesirable effects on the public budget, these are however neutralized by the favorable effects of fossil fuel prices, and to a lesser extent carbon taxes. The fact that the bulk of the reduction in public debt is induced by the evolution of the fossil-fuel prices also leaves sufficient leeway to increase the mix of energy efficiency relative to carbon taxation, while avoiding a deterioration of the budgetary situation.

\section{Summary and Conclusions}

We assess the relative role of fossil-fuel prices, energy efficiency and carbon taxation in reaching environmental targets using a dynamic general-equilibrium model of the Portuguese economy that features endogenous growth and a detailed modeling of all major public sector activities. We have identified important and clearly differentiated environmental, economic and budgetary effects associated with each of these three drivers of reductions in carbon emissions.

The consideration of the impacts of the different drivers on energy and emissions, economy and public budget are very informative from a policy perspective. First, to achieve the ambitious emissions reductions goal of $40 \%$, compared to the 1990 levels, and conditional on 
the expected evolution of international fuel prices, the roles of promoting energy efficiency and of a new significant carbon tax are fundamental, and have to be both fully embraced. Specifically, we estimate that, under the reference-price scenario, a steady energy efficiency gain of $2-2.5 \%$ and a carbon tax of at least $35 €$ per $\mathrm{tCO}_{2}$ are necessary. Second, promoting energy efficiency and a new carbon tax have rather different economic and budgetary effects. Energy efficiency achieves reductions in emissions while promoting economic performance but with a risk of increasing public and foreign debt. In turn, the new carbon tax achieves reductions in emissions but at a risk of jeopardizing economic performance, while the effects on public and foreign debt are more favorable. This being the case, the relevance of pursuing both strategies in tandem is clear. Third, while the domestic authorities can control efforts toward promoting energy efficiency and the introduction of a new carbon tax, what is needed is in great measure determined by the actual evolution of the international fossil-fuel prices. This evolution has significant effects on emissions, and thereby also on the measure of the additional effects required from the domestic authorities.

Despite the robustness of the general recommendations derived from our results, the specifics of the results have, naturally, to be understood in their proper context. First, energy efficiency gains are considered costless in our setting. While this is justifiable, since all of the energy technologies are cost-effective and should be adopted by the economy for that reason alone, it is also well understood how difficult these potential energy efficiency gains are to actually implement given the potential alternative uses of those resources. Large investments are often necessary to promote, publicize and subsidize the adoption of these technologies on a large scale. In this sense, our projections of the economic effects of energy efficiency should be understood as upper bounds. In terms of emissions, however, a lower rebound effect could lead to an even more favorable outcome, and therefore, from this perspective, our projections could be thought of as lower bounds. Second, in the context of the new carbon tax, we have not considered any strategies for recycling revenues raised by the tax, an issue that is well understood 
as having the potential to mitigate any adverse effects of the tax besides the potential to be used to promote energy efficiency itself [see, for example, Marron and Toder (2014) and Pereira and Pereira (2014b)]. In this sense, the economic effects of the carbon taxes we project here can be understood as lower bounds - i.e., the worst possible outcome. In turn, recycling by mitigating the economic effects would also somewhat reduce the gains in emissions. Accordingly, the carbon emissions effects of the carbon taxes we project here van be understood as upper bounds - i.e., the best possible outcome.

As an epilogue to this study, it is worth mentioning that the evidence discussed here was fully considered by the Portuguese Commission for Environmental Tax Reform (CRFV), and that the views and recommendations we present were fully taken in to account in the official reform proposal. Specifically, this proposal considered the need for a carbon tax in Portugal of the magnitude indicated in this paper, as well as the importance of linking it to objectives of energy efficiency [see CRFV (2014)]. A carbon tax indexed to the price of carbon emissions in the European Union Emissions Trading System became law in Portugal as of January 1, 2015.

To conclude, although this study is an application to the Portuguese case, and it served directly to inform policy making in Portugal, its interest is far from parochial. Naturally, climate and energy are both at the center of the policy concerns and objectives in the EU [see, for example, European Commission (2014b, 2014c)] and, as such, all European countries need to deal, albeit in different degrees, with these issues. In addition, there is a growing chorus of institutional voices urging the different countries to adopt green taxes [see, for example Eurogroup (2014), IMF (2014), OECD (2014), Parry et al. (2014), and World Bank (2014)]. Furthermore, from the perspective of policy evaluation, the interactions between climate policy, economic growth and the public sector account are fundamental, since they correlate to the most important policy constraints faced by less-developed energy-importing economies in their pursuit of sound climate policies: the need to implement policies that promote long-term growth and strengthen fragile public budgets. 


\section{REFERENCES}

Agência Portuguesa do Ambiente. 2012. A National Roadmap to Low Carbon 2050. Ministério da Agricultura, do Mar, do Ambiente e do Ordenamento do Território. Lisboa, Portugal.

Allan, G., Hanley, N., McGregor, P., Swales, J., and K. Turner. 2007. The impact of increased efficiency in the industrial use of energy: A computable general equilibrium analysis for the United Kingdom. Energy Economics 29 (4): 779-798.

Anderson, M., Speck, S., and D. Gee. 2013. Environmental Fiscal Reform - Illustrative Potential for Portugal. European Environment Agency Staff Position Note 13/01.

Babiker, M., Metcalf, G., and J. Reilly. 2003. Tax distortions and global climate policy. Journal of Environmental Economics and Management 46 (2): 269-287.

Balcilar, M., Ozdemir, Z., and Y. Arslanturk. 2010. Economic growth and energy consumption causal nexus viewed through a bootstrap rolling window. Energy Economics 32(6): 1398-1410.

Barker, T., Baylis, S., and P. Madsen. 1993. A UK carbon/energy tax: The macroeconomics effects. Energy Policy 21(3), 296-308.

Barker, T., Paul, E., and T. Foxon, 2007. Macroeconomic effects of efficiency policies for energy-intensive industries: The case of the UK Climate Change Agreements, 2000-2010. Energy Economics 29(4): 760-778.

Bergman, L. 2005. CGE modeling of environmental policy and resource management. In Handbook of Environmental Economics (Volume 3), Karl-Göran Mäler and Jeffery R. Vincent, Ed., 1273-1306. Amsterdam: North Holland.

Brookes, L., 1990. The Greenhouse effect: the fallacies in the energy efficiency solution. Energy Policy. 18: 199-201.

Bovenberg, L., and R. de Mooij. 1997. Environmental tax reform and endogenous growth. Journal of Public Economics 63: 207-237.

Carraro, C., de Cian, E., and M. Tavoni. 2012. Human capital formation and global warming mitigation: evidence from an integrated assessment model. CEPR Working Paper 8919.

Comissão da Reforma da Fiscalidade Verde [CRFV]. 2014. Projecto de Refoma da Fiscalidade Verde, Ministério do Ambiente do Ordenamento do Território e da Energia. Lisboa, Portugal.

Conefrey, T., FitzGerald, J., Valeri, L., and R. Tol. 2013. The impact of a carbon tax on economic growth and carbon dioxide emissions in Ireland. Journal of Environmental Planning and Management 56(7): 934-952.

Conrad, K. 1999. Computable general equilibrium models for environmental economics and policy analysis. In Handbook of Environmental and Resource Economics, Jeroen van den Bergh, Ed., Cheltenham: Edward Elgar.

Direcção-Geral de Energia e Geologia [DGEG]. 2014. Factura Energética Portuguesa. Ministério da Economia. Lisboa, Portugal.

Dissou, Y. 2005. Cost-effectiveness of the performance standard system to reduce $\mathrm{CO}_{2}$ emissions in Canada: A general equilibrium analysis. Resource and Energy Economics 27(3),187207.

Esteves, P. 2014. Cenário da Evolução do Preço dos Combustíveis: Anexo II do Relatório Técnico "Sobre os Efeitos Ambientais e Económicos de uma Nova Tributação sobre o Carbono em Portugal - Anexo II". Relatório Técnico apresentado à Comissão de Reforma da Fiscalidade Verde. Lisboa, Portugal. 
EC Directive 2009/28/EC of the European Parliament and of the Council of 23 April 2009.

Eurogroup. 2014. Structural Reform Agenda - Thematic Discussions on Growth and Jobs Reduction of the Tax Wedge. Press Statement, July 8, 2014.

European Commission. 2013. Green Paper - A 2030 Framework for Climate and Energy Policies. Brussels.

European Commission. 2014a. Progress Towards Achieving Kyoto and EU 2020 Objectives. Brussels.

European Commission. 2014b. A Policy Framework for Climate and Energy in the Period 2020 up to 2030. Brussels.

European Commission. 2014c. Impact Assessment - Accompanying the Communication A Policy Framework for Climate and Energy in the Period 2020 up to 2030. Brussels.

European Commission. 2014d. Statistical annex of the European economy. Spring 2014 European Economy. Directorate General for Economic and Financial Affairs, Brussels.

European Commission. 2014e. EU Energy, Transport, and Emissions Trends to 2050 - Reference Scenario 2013. Directorate General for Energy, Directorate General for Climate Action, and Directorate General for Mobility and Transport.

Farmer, K., and Steininger, K. 1999. Reducing $\mathrm{CO}_{2}$ - emissions under fiscal retrenchment: a multi-cohort CGE-model for Austria. Environmental and Resource Economics 13 (3): 309-340.

Fullerton, D., and Kim., S-R. 2008. Environmental investment and policy with distortionary taxes, and endogenous growth. Journal of Environmental Economics and Management 56 (2): 141154.

Gabinete de Planeamento, Estratégia, Avaliação e Relações Internacionais [GPEARI]. 2014. Estatística das Finanças Públicas. Ministério das Finanças e da Administração Pública. Lisboa, Portugal.

Glomm, G., Kawaguchi, D., and F. Sepúlveda. 2008. Green taxes and double dividends in a dynamic economy. Journal of Policy Modeling 30(1): 19-32.

Greiner, A. 2005. Fiscal policy in an endogenous growth model with public capital and pollution. The Japanese Economic Review 56 (1): 67-84.

Grepperud, S., and I. Rasmussen. 2004. A general equilibrium assessment of rebound effects. Energy Economics 26(2): 261-282.

Gupta, M., and T. Barman. 2009. Fiscal policies, environmental pollution and economic growth. Economic Modelling. 26 (5): 1018-1028.

Haita, C., 2012. The State of Compliance in the Kyoto Protocol, International Center for Climate Governance Reflection No 12/2012.

Hamilton, J. 2009. Understanding crude oil prices. The Energy Journal. 30(2): 179-206.

Hanley, N., McGregor, P., Swales, J., and K. Turner. 2006. The impact of a stimulus to energy efficiency on the economy and the environment: A regional computable general equilibrium analysis. Renewable Energy 31(2): 161-171.

Hanley, N., McGregor, P., Swales, J. and K. Turner. 2009. Do increases in energy efficiency improve environmental quality and sustainability? Ecological Economics 68(3) 692-709.

He, Y., Wang, S., Lai, K. (2010) Global economic activity and crude oil prices: A cointegration analysis. Energy Economics. 32(4): 868-876. 
Heijdra, B., Kooiman, J., and J. Ligthart, 2006. Environmental quality, the macroeconomy, and intergenerational distribution. Resource and Energy Economics 28(1): 74-104.

Intergovernmental Panel on Climate Change. 2006. Revised 1996 IPCC Guidelines for National Greenhouse Gas Inventories: Reference Manual. United Nations Framework Convention on Climate Change. http://www.ipcc-nggip.iges.or.jp/public/2006gl/index.html

International Monetary Fund. 2014. Fiscal Policy to Address Energy's Environmental Impacts. IMF Surveys.

Khazzoom, J. 1980. Economic implications of mandated efficiency standards for household appliances. Energy Journal. 1(2): 21-40.

Koeppl, A., Kratena, K., Pichl, C., Schebeck, F., and S. Schleicher. 1996. Macroeconomic and sectoral effects of energy taxation in Austria. Environmental and Resource Economics 8(4): 417 430.

Koetse, M., Henri, L., de Groot, R., and J. Florax. 2008. Capital-energy substitution and shifts in factor demand: A meta-analysis. Energy Economics 30(5): 2236-2251.

Korhonen, I., and S. Ledyaeva. 2010. Trade linkages and macroeconomic effects of the price of oil. Energy Economics 32(4):848-856.

Manne A., and R. Richels. 1992. Buying Greenbouse Insurance - the Economic Costs of Carbon Dioxide Emission Limits. MIT Press, Cambridge.

Marron, D., and E. Toder. 2014. Tax Policy Issues in Designing a Carbon Tax. American Economic Review Papers and Proceedings 104(5): 563-568.

Martinsen, D., V. Krey, and P. Markewitz. 2007. Implications of high energy prices for energy system and emissions - The response from an energy model for Germany. Energy Policy. 35(9): 4504-4515.

Metcalf. G, and D. Weisbach. 2008. The Design of a Carbon Tax. Discussion Papers Series, Department of Economics, Tufts University 0727, Department of Economics, Tufts University.

Metcalf, G. 2009. Designing a Carbon Tax to Reduce U.S. Greenhouse Gas Emissions. Review of Environmental Economics and Policy 3(1): 63-83, Association of Environmental and Resource Economists.

Metcalf, G. 2010. Submission on the Use of Carbon Fees to Achieve Fiscal Sustainability in the Federal Budget. Submission to Commission Jul. 2010. Available at: http://works.bepress.com/gilbert_metcalf/86.

Nordhaus, W. 1993a. Optimal Greenhouse-Gas Reductions and Tax Policy in the 'Dice' Model. American Economic Review. 83(2): 313-17.

Nordhaus, W. 1993b. Rolling the 'DICE': an optimal transition path for controlling greenhouse gases. Resource and Energy Economics, 15(1): 27-50.

Metcalf. G., and D. Weisbach. 2008. The Design of a Carbon Tax. Discussion Papers Series, Department of Economics, Tufts University 0727, Department of Economics, Tufts University.

OECD (2014). Deepening Structural Reform to Support Growth and Competitiveness. Brussels.

Paltsev, S., Reilly, J., Jacoby, H., Eckaus, R., McFarland, J., Sarofim, M., Asadoorian, M., and M. Babiker. 2005. The MIT Emissions Prediction and Policy Analysis (EPPA) Model: Version 4. MIT Joint Program on the Science and Policy of Global Change Report 125. 
Parry, I., D. Heine, E. Lis, and S. Li. 2014. Getting Energy Prices Right: From Principles to Practice. International Monetary Fund.

Pereira, A., and R. Pereira. 2012. DGEP - a dynamic general equilibrium model of the Portuguese economy: model documentation. The College of William and Mary, Working Paper 127 (Revised 2014).

Pereira, A., and R. Pereira. 2013. Fossil fuel prices and the economic and budgetary challenges of a small energy-importing economy: the case of Portugal. Portuguese Economic Journal. 12(3): 181-214.

Pereira, A., and R. Pereira. 2014a. What is it going to take to achieve 2020 Emission Targets? Marginal abatement cost curves and the budgetary impact of CO2 taxation in Portugal. Working Papers 105, Department of Economics, College of William and Mary.

Pereira, A., and R. Pereira. 2014b. Environmental Fiscal Reform and Fiscal Consolidation: The Quest for the Third Dividend in Portugal. Public Finance Review 42(2): 222-253.

Pereira, A., and R. Pereira. 2014c. On the environmental, economic and budgetary impacts of fossil fuel prices: A dynamic general equilibrium analysis of the Portuguese case. Energy Economics. 42(C): 248-261.

Pereira, A., and P. Rodrigues. 2002. On the Impact of a Tax Shock in Portugal. Portuguese Economic Journal 1(3), 205-236.

Pereira, A., and P. Rodrigues. 2004. Strategies for fiscal reform in the context of the EMU: the case of Portugal. Review of Development Economics 8(1): 143-165.

Pereira, A., and P. Rodrigues 2007. Social security reform in Portugal: A Dynamic General Equilibrium Analysis. Portuguese American Development Foundation, Lisbon.

Rivers, N., 2010. Impacts of climate policy on the competitiveness of Canadian industry: How big and how to mitigate? Energy Economics 32(5): 1092-1104.

Saunders, D., 1992. The Khazzoom-Brookes postulate and neoclassical growth. Energy Journal. 13 (4), 131-148.

Saunders, H., 2000. A view from the macro side: rebound, backfire and Khazzoom-Brookes. Energy Policy 28(6-7): 439-449.

Saunders, H., 2008. Energy conserving (and using) production functions. Energy Economics 30 (5): 2184-2235.

Seixas, J., and P. Fortes. 2014. Avaliação do Impacto da Taxa de $\mathrm{CO}_{2}$ no Sistema Energético em Portugal o Modelo TIMES_PT. "Sobre os Efeitos Ambientais e Económicos de uma Nova Tributação sobre o Carbono em Portugal - Anexo III”. Relatório Técnico apresentado à Comissão de Reforma da Fiscalidade Verde. Lisboa, Portugal.

Stern, N. 2007. The Economics of Climate Change: The Stern Review. Cambridge University Press.

van Ruijven, B., and D. van Vuuren. 2009. Oil and natural gas prices and greenhouse gas emission mitigation. Energy Policy 37(11): 4797-4808.

Turner, K. 2009. Negative rebound and disinvestment effects in response to an improvement in energy efficiency in the UK economy. Energy Economics 31(5): 648-666.

Wei, T. 2010. A general equilibrium view of global rebound effects. Energy Economics 32(3): 661672.

World Bank. 2014. State and Trends of Carbon Pricing. World Bank, Washington, DC. 